\title{
India's Emerging Trends Of Higher Education during Late Pt. J.L. Nehru's Era 1947-64
}

\author{
Dr. Kumari Vineeta \\ Faculty of Education, S.M. College, Bhagalpur, T.M. Bhagalpur University, Bhagalpur, India.
}

\begin{abstract}
Right from Aryavart via Bharat to India happens to be the largest education system in all the periods including today only after China. According to the world book CIA 2004 estimation, at present India has approximately thirty five percent youth are under eighteen years of age. Ancient educational system has been elitist and traditional. Hindu education was tailored to the Brahmin and by the Brahmin, a class of society involved in education and educating as educator. According to Hindu scriptures it was not a caste but community involved in earning knowledge as taught and teacher. This historical bulwark conjoins with postindependence centrum on higher education created an explosion in higher education during Pt. Nehru's period (1947-64).Being farsighted person he recognized the urgency of technical education to produce technocrats of International knowhow and established five Indian Institute of Technology and Indian Institute of Management locating them in different region to satisfy regional imbalance attitude and that made India to capitalize large number of well-educated person and became a major exporter of software workers. Creation of UGC, NCERTand AICTEbecomes a mile stone in promoting higher education in the nation. Pre-independence India had only 20 universities and there was no agenda before the government for the research and development, emphasis was on English language, science, mathematics, technology was not on the priority of the British government, most of the ideas were exotic. In FFYP-8\%, $2 F Y P-18 \%$ and in $3 F Y P-16 \%$ was the plan expenditure on higher education.
\end{abstract}

Keywords: Resurgence, endowment, amusements,incarnation, exigency,placebo,unaccustomed,tenaciously, apropos, exotic, boon, infliction

\section{Background Of The Study}

As my research work is focussed on higher education with reference to India, so it becomes essential to examine the origin of its achievement in ancient age. The story of present India a segment of Jamboodeev starts from Aryavarta moving towards Bharatvarsh, to Hindustan. There are several testaments in which demography of Aryavarta, Bharatvarsh hasbeen mentioned as recited inthis Sanskrit shlokas uttaramyatsamundrasyaHimaadreshehaivaDakshenam | varshamtadaBharatamNaamBharatiYatraSantatihl \|

- Vishnu puran-2.3.1

It means, north of the ocean and south of the Himalayas is the land of Bharat. It has also been described as from Himalayas, all the way to the Ocean the God has created the sacred land of Hindustan as recited in Sanskrit shlokas as,

\section{himalayamsamaarabhyayaaavadindusarovaram $\mid$ tamdevanirmitamdeshamhindusthaanamprachakshatey \|}

At present it is republic India in its smallest form since its inception with $3268081 \mathrm{~km}^{2}$ (ref. survey of India 1965).India got independence on $15^{\text {th }}$ August, 1947 at 12.02 AM having population of only 35 crores having population density 138/sq.km.

Here, my study is restricted to the study of development that has taken in the field of higher education after independence and during the period of Prime Minister Late Pt. Jawaharlal Nehru a farsighted statesman of the India. Henceto begin my study, I have to examine the pre independence position of education that was existing in India with their social acceptability and sustaining power particularly extent of financial input and the quality educational output. Prior to this, I have to examine the importance of education for human being of those days. On-going through the literature, I observed that the prominent thinker/social reformers/educators/Maharishis (sage) and those entire person who have been accepted by the society of that time as incarnation of God Vishnu and their thought regarding education. In ancient India educational system was monitored by a class of people called Brahmana andtheir working, culture, and routine all were under the frame work of the dharma.

bhootanam praninah shresthah, praninam budhijeevinah $\mid$

budhimatsu narah shrestha nareshu bhahmanh smitah\| 
It goes without saying that Brahmanas are at the acme of the enlightenment in that days at the same time a strong restrain was also imposed over the functioning of Brahmanas also ref.

brahmansya tu dihoayam na sukhay kadachanal tapah klishaay dharmay pretya mokshya sharbadal

- Manusmriti 9.99

It says that Brahmanas have to always involve themselves in growing knowledge; their body is not meant for pleasure. The most sacred book of Hindu scriptures i.e.B.Gita, that got worldwide recognition in which God Krishna has classified Brahmanas ref. 18.42 B. Gita.

$$
\begin{aligned}
& \text { samo damas tapah saucam ksantir arjavam eva ca } \mid \\
& \text { jnanam vijnanam astikyam brahma-karma svabhava-jam } \|
\end{aligned}
$$

-B.Gita-18.42

\section{brahmnah kshtriya vaishya madhye shudrasca bhagshah|}

Raja Bhartari Hari a noted scholar of ancient India having practical experience in his own life term as Monarch, as chivalrous and finally as salvation has expressed his view through Sanskrit shlokas in his epic Neeti shatak recited as.

$$
\begin{aligned}
& \text { vidya naam narasya roopamadhikam prachhnnaguptam dhanam|| } \\
& \text { vidya bhogkari yashah sukhkari vidya gurunam guruh } \| \\
& \text { vidya bandhjano bideshgamane vidya para clevata| } \\
& \text { vidya rajasu poojita na tu dhanam vidyaviheenah pashuh\| }
\end{aligned}
$$

-Neeti Shatak-20.0

Here, Vidya stands for education and without whichhuman is not more than animal and is a means for all comfort and amusements, get social respect \& protection in an unaccustomed assembly. The great economist Kautilya has also expressed the coalescent view through his shlokas in Chanakya Neeti.

$$
\begin{aligned}
& \text { vidyamitramparashesumata mitram griheshu ca| } \\
& \text { vyadhitasyoaushadhimitram dharma mitrammritasyaca } \mid
\end{aligned}
$$$$
\text { -Chanakya Neeti-17.1 }
$$

Education is like our companion in foreign, like placebo for sick and righteousness (Dharma) for passing people.

Ancient India had the Gurukul pattern of imparting education and it was named by their head called Guru and institution was named as Guru's Ashram like Sandeepan Ashram, Vashishta's Ashram. The Guru taught everything the child willing to learn from Sanskrit to Holy Scriptures and from Mathematics to Meta Physics or even Military Science to fight war. From ancient Aryavart to modern India, higher education has always occupied a place of prominence in Indian history. In ancient times, Nalanda, Taxila and Vikramsila universities were renowned seats of higher learning, attracting students not only from all over the country but from far off countries like Korea, China, Burma (now Myanmar), Ceylon (now Sri Lanka), Tibet and Nepal. Today, India manages one of the largest higher education systems in the world. The present system of higher education dates back to Mount Stuart Elphinstone's minutes of 1823, which stressed on the need for establishing schools for teaching English and the European sciences. Later, Lord Macaulay, in his minutes of 1835, advocated "efforts to make natives of the country thoroughly good English scholars". Sir Charles Wood's Dispatch of 1854, famously known as the 'Magna Charta of English Education in India', recommended creating a properly articulated scheme of education from the primary school to the university. It sought to encourage indigenous education and planned the formulation of a coherent policy of education. Subsequently, the universities of Calcutta, Bombay (now Mumbai) and Madras were set up in 1857, followed by the University of Allahabad in 1887. The Inter-University Board (later known as the Association of Indian Universities) was established in 1925 to promote university activities, by sharing information and cooperation in the field of education, culture, sports and allied areas. The first attempt to formulate a national system of education in India came in 1944, with the Report of the Central Advisory Board of Education (CABE) on Post War Educational Development in India, also known as the Sargent Report. It recommended the formation of a University Grants Committee (UGC), which was formed in 1945 to oversee the work of the three Central Universities A.M.U., B.H.U.and Delhi. In 1947, the Committee was entrusted with the responsibility of dealing with all the then existing Universities.

In the year 1921 Uttar Pradesh Board of high school and Intermediate education was the first Board of India to be setup with jurisdiction over Rajputana, Central India, and Gwalior and later on several State Boards were setup. In those days intermediate education was also the part of higher education. The pre independence universities and their year of establishment with working character are mentioned in Table-1. 
India's Emerging Trends Of Higher Education during Late Pt. J.L. Nehru's Era 1947-64

Table 1. UNIVERSITIES IN INDIA with their Character, Intake, Strength \& Expenditure Pre Independence (1947)

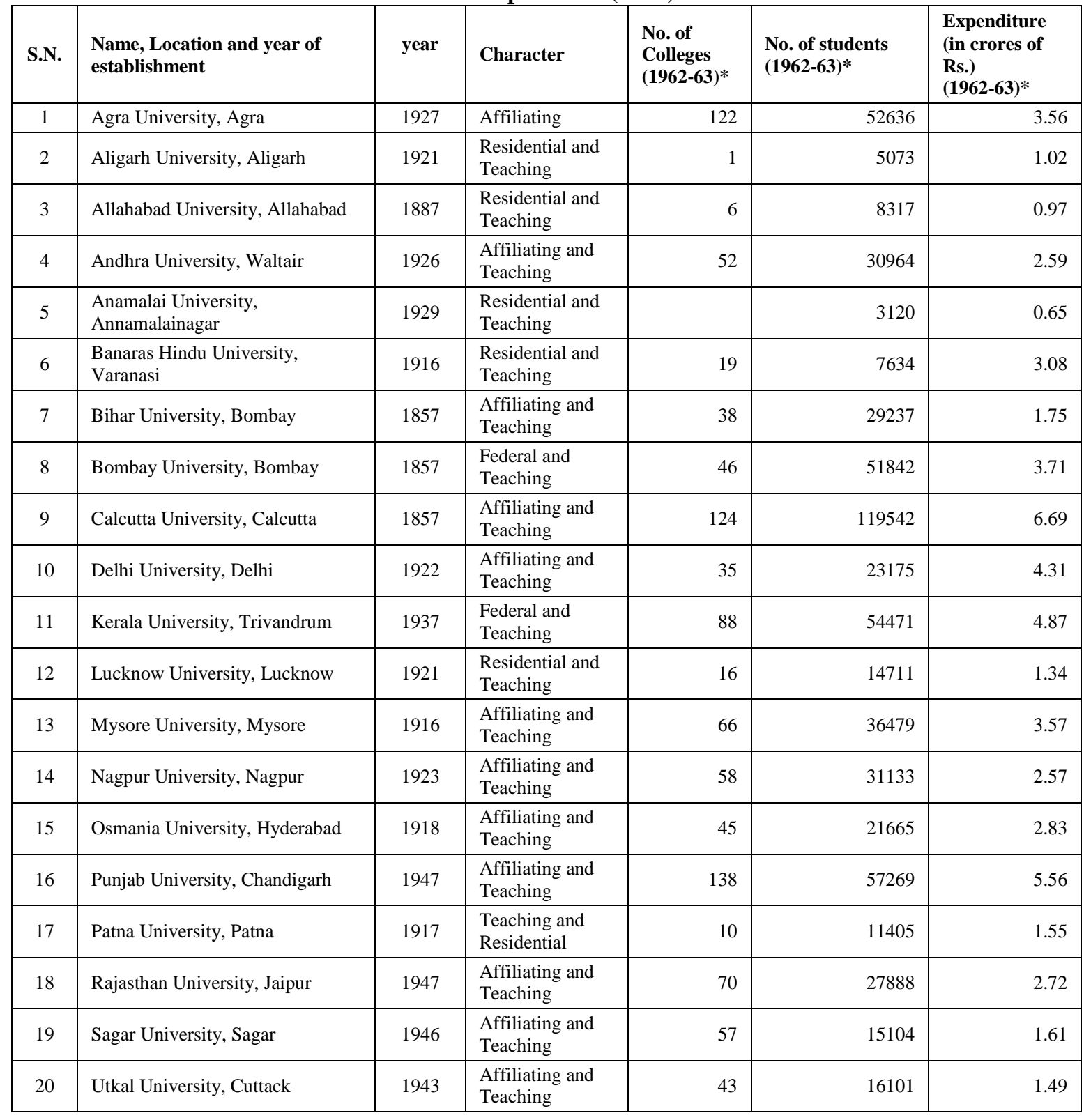

Table 2.Pre-independence state breakup of enrolment

\begin{tabular}{|c|c|c|c|}
\hline Provinences & $\begin{array}{l}\text { Graduate, Post-Graduate } \\
\text { degrees in General } \\
\text { Education }\end{array}$ & Professional Colleges & $\begin{array}{l}\text { Special \& Vocational } \\
\text { Schools }\end{array}$ \\
\hline Assam & 937 & 126 & 20,864 \\
\hline Bengal & 11,562 & 9,334 & $2,02,264$ \\
\hline Bihar & 3,285 & 1,466 & 20,999 \\
\hline Bombay & 8,419 & 7,862 & $1,08,772$ \\
\hline C.P. \& Berar & 1,860 & 1,919 & 4,982 \\
\hline Madras & 9,678 & 5,188 & 41,536 \\
\hline N.W.F.P. & 298 & 36 & 215 \\
\hline Orissa & 948 & 229 & 3,807 \\
\hline Punjab & 8,633 & 3,953 & 10,653 \\
\hline Sind & 1,158 & 684 & 3,332 \\
\hline United Provinces & 11,937 & 12,253 & 78,554 \\
\hline Ajmer-Merwara & 214 & 66 & 460 \\
\hline Baluchistan & - & - & 27 \\
\hline Bangalore & 162 & - & 96 \\
\hline Coorg & - & - & 55 \\
\hline Delhi & 2,232 & 998 & 1,642 \\
\hline
\end{tabular}


India's Emerging Trends Of Higher Education during Late Pt. J.L. Nehru's Era 1947-64

\begin{tabular}{|c|c|c|c|}
\hline Provinences & $\begin{array}{l}\text { Graduate, Post-Graduate } \\
\text { degrees in General } \\
\text { Education }\end{array}$ & Professional Colleges & $\begin{array}{l}\text { Special \& Vocational } \\
\text { Schools }\end{array}$ \\
\hline Minor Administrations & - & - & 689 \\
\hline
\end{tabular}

Source : Progress of Education in India (1937-47), Vol. II, pp. 22-23

The first and foremost in the growth of science and technology and large expansion of trained scientific and technical manpower engineering education which lacked both quality and quantity in 1947 need improvement Agricultural and Medical Education were also at nominal point only 17institutions for higher education in Agriculture was upto 1947 and number medical colleges before freedom were only fifteen with annual intake of about 1200 students. The maintenance of standards in education was extremely crucial and there was only $0.5 \%$ of the national income was the expenditure on education including primary, secondary and higher education.

\section{Purpose Of The Study}

The objective of the study was to examine the apropos of steps taken in that period may be called the endowment period of higher education is to how much extend is relevant in the present scenario after lapse of about 70 years of its inception. When the populations has increased almost four times with reference to that at the time of freedom and we have lost some demographic area by the partition of country on religious ground and some portion as a result of defeat in the 1962 Chinese aggression.

\section{Limitation Of The Study}

Although my plan is to study the entire educational system weather primary, secondary and higher education starting from Independence Day and prevailing till date and I have divided my project into several segments. The first among these is present here. Hence our all studies is limited to the tenure of $1^{\text {st }}$ Prime Minister Period i.e. 1947-64.

\section{Resurgence Of Higher Education After Freedom}

After a long struggle for freedom, ultimately the British rules declared India a free country on when the nation was facing an ever present danger of famine having high rate of population growth about twice that of USA and four times of UK. Country was facing a challenge of stable economy where men had tenaciously too many religions and faith. With the portion of India on religious ground followed by communal riot country was in turbulent state. The habit of "Civil disobedience" and non-cooperation have inherited in the mass due to lingering of liberation movement might not easily be discarded from the nature of men.

An estimated data indicating that about 80 to $90 \%$ population were illiterate. Our leadership of free India looked to education as one of the most potent one to combat poverty and starvation. They resolved that for ten years free and compulsory education to all children under fourteen years would be provided. In order to achieve the declared goal needs largest infusion of cash in education sector but Govt. of India couldn't allocate more than $5 \%$

of its national budget to education whereas France allocated $12 \%$ and UK about $11 \%$ on education.

\section{Graph 1: Literacy rate in India}

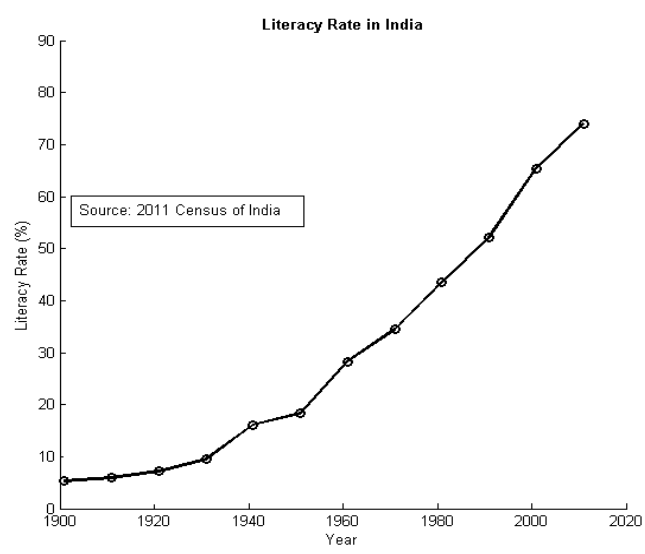


The journey of growth of higher education in free India began with the constitution of University Education Commission under the chairmanship of Dr. S. Radhakrishnan with ten other members. The commission started working in 1948 and submitted its report with recommendation in August 1949.

On the recommendation of S. Radhakrishnan Committee in 1949, the University Grant Commission came into existence in the pattern of U.K but its area was restricted only to A.M.U, B.H.U and D.U.Present form of UGC came in November 1956 as statutory body of the Government of India through an act of Parliament as Dr. C.D.Deshmuhk was the first Chairman having all Indian Territory as its jurisdictions. The Chairman as top Executive and other members were appointed from the reputed educationist of the country. The National Council of Education Research and Training (NCERT) established in 1961 and charged with the function of (i) undertaking, aiding and promoting research in all branches of educations; (ii) organizing advanced pre-service and in-service training, disseminating improved techniques and educational research and training of teachers, and (iii) developing and improving multi-purpose secondary education. The council has also started a training course in Research Methodology in Education from 1963.

The research and teacher's training programmes of the Council are developed through the National Institute of Education at New Delhi and four regional colleges of education at Ajmer, Bhubaneswar, Bhopal and Mysore. The Institute's programme is at present being implemented by its constituent units-the National Institute of Audio-Visual Education, the National Institute of Basic Education, the Directorate of Extension Programmes for Secondary Education, the Central Institute of Education, the National Fundamental Education Centre, the Central Bureau of Educational and Vocational Guidance, the Department of Science Education and the Central Bureau of Textbook Research.It was assigned the task of developing quality education research, funding, affiliating \& strengthening institution in national interest.

When we look back educational situation on the eve of independence, we then had 17 universities and 636 colleges with total enrolment of only 2,38,000 students, 5,297 Secondary schools with 8,70,000 students which implied that not even one youth in every twenty in the age group of 15-18 was in school.

Table 3.UNIVERSITIES IN INDIA with their Character, Intake, Strength \& Expenditure Post-Independence: 1948 - 64

\begin{tabular}{|c|c|c|c|c|c|c|}
\hline S.N. & $\begin{array}{l}\text { Name, Location and year of } \\
\text { establishment }\end{array}$ & Year & Character & $\begin{array}{c}\text { No. of } \\
\text { Colleges } \\
(1962-63)^{*}\end{array}$ & $\begin{array}{l}\text { No. of students } \\
(1962-63) *\end{array}$ & $\begin{array}{c}\text { Expenditure } \\
\text { (in crores of } \\
\text { Rs.) } \\
(1962-63) *\end{array}$ \\
\hline 1 & $\begin{array}{l}\text { Agriculture University, } \\
\text { Ludhiana }\end{array}$ & 1962 & $\begin{array}{l}\text { Residential and } \\
\text { Teaching }\end{array}$ & & & \\
\hline 2 & $\begin{array}{l}\text { Andhra Pradesh Agricultural } \\
\text { University, Hyderabad }\end{array}$ & 1964 & & & & \\
\hline 3 & Bangalore University, Bangalore & 1964 & & & & \\
\hline 4 & $\begin{array}{l}\text { Bhagalpur University, } \\
\text { Bhagalpur }\end{array}$ & 1960 & $\begin{array}{l}\text { Affiliating and } \\
\text { Teaching }\end{array}$ & 35 & 21599 & 1.45 \\
\hline 5 & $\begin{array}{l}\text { Burdwan University, Burdwan } \\
\text { West Bengal }\end{array}$ & 1960 & $\begin{array}{l}\text { Affiliating and } \\
\text { Teaching }\end{array}$ & 47 & 21782 & 1.58 \\
\hline 6 & Guwahati University, Guwahati & 1948 & $\begin{array}{l}\text { Affiliating and } \\
\text { Teaching }\end{array}$ & 47 & 26391 & 2.9 \\
\hline 7 & $\begin{array}{l}\text { Gorakhpur University, } \\
\text { Gorakhpur }\end{array}$ & 1957 & $\begin{array}{l}\text { Affiliating and } \\
\text { Teaching }\end{array}$ & 28 & 14814 & 0.8 \\
\hline 8 & Gujarat University, Ahmedabad & 1949 & $\begin{array}{l}\text { Affiliating and } \\
\text { Teaching }\end{array}$ & 80 & 46502 & 3.14 \\
\hline 9 & $\begin{array}{l}\text { Indira Kala Sangeet } \\
\text { Vishwavidyalaya, Khairagarh }\end{array}$ & 1956 & $\begin{array}{l}\text { Affiliating and } \\
\text { Teaching }\end{array}$ & 30 & 147 & 0.01 \\
\hline 10 & $\begin{array}{l}\text { Indore University, } \\
\text { Indore }\end{array}$ & 1964 & & & & \\
\hline 11 & Jabalpur University, Jabalpur & 1957 & $\begin{array}{l}\text { Affiliating and } \\
\text { Teaching }\end{array}$ & 20 & 10000 & 0.89 \\
\hline 12 & Jadavpur University, Jadavpur & 1955 & $\begin{array}{l}\text { Residential and } \\
\text { Teaching }\end{array}$ & 3 & 3587 & 0.71 \\
\hline 13 & $\begin{array}{l}\text { Jammu and Kashmir University, } \\
\text { Srinagar }\end{array}$ & 1948 & $\begin{array}{l}\text { Affiliating and } \\
\text { Teaching }\end{array}$ & 32 & 10569 & 0.14 \\
\hline 14 & $\begin{array}{l}\text { Jawaharlal Nehru Krishi- } \\
\text { Vishwa-Vidyalaya, Jabalpur }\end{array}$ & 1964 & & & & \\
\hline 15 & Jiwaji University, Gwalior & 1964 & & & & \\
\hline 16 & Jodhpur University, Jodhpur & 1962 & $\begin{array}{l}\text { Residential and } \\
\text { Teaching }\end{array}$ & 1 & 4530 & 0.35 \\
\hline
\end{tabular}


India's Emerging Trends Of Higher Education during Late Pt. J.L. Nehru's Era 1947-64

\begin{tabular}{|c|l|c|l|c|c|c|}
\hline S.N. & $\begin{array}{l}\text { Name, Location and year of } \\
\text { establishment }\end{array}$ & Year & Character & $\begin{array}{c}\text { No. of } \\
\text { Colleges } \\
(\mathbf{1 9 6 2 - 6 3})^{*}\end{array}$ & $\begin{array}{c}\text { No. of students } \\
(\mathbf{1 9 6 2 - 6 3})^{*}\end{array}$ & $\begin{array}{c}\text { Expenditure } \\
\text { (in crores of } \\
\text { Rs.) } \\
(\mathbf{1 9 6 2 - 6 3}) *\end{array}$ \\
\hline 17 & $\begin{array}{l}\text { Kalyani University, Kalyani } \\
\text { (West Bengal) }\end{array}$ & 1960 & $\begin{array}{l}\text { Residential and } \\
\text { Teaching }\end{array}$ & 1 & 471 & 0.37 \\
\hline 18 & $\begin{array}{l}\text { Kameshwara Singh Darbhanga } \\
\text { Sanskrit University, Darbhanga }\end{array}$ & 1961 & $\begin{array}{l}\text { Residential and } \\
\text { Teaching }\end{array}$ & & & \\
\hline 19 & Karnatak University, Dharwar & 1949 & $\begin{array}{l}\text { Affiliating and } \\
\text { Teaching }\end{array}$ & 39 & 16964 & 1.29 \\
\hline 20 & $\begin{array}{l}\text { Kurukshetra University, } \\
\text { Kurukshetra }\end{array}$ & 1956 & $\begin{array}{l}\text { Residential and } \\
\text { Teaching }\end{array}$ & 3 & 797 & 0.36 \\
\hline
\end{tabular}

Besides these universities, there are a large number of institutions which impart higher learning. The Birla Institute of Technology and Science, Pilani, the Indian Agricultural Research Institute, Delhi, the Indian Institute of Science, Bangalore, the Jamia Millia Islamia, New Delhi, the Indian School of International Studies, New Delhi, the Gurukul Kangri Vishwavidyalaya, Hardwar, the Kashi Vidyapith, Varanasi, Gujarat Vidyapith, Ahmedabad and the Tata Institute of Social Sciences, Bombay, have been deemed to be Universities for the purposes of the University Grants Commission Act, 1956. Many of the research laboratories and institutions are recognized by the Inter-University Board as Centres of higher research. Some of them under take teaching as well. Besides these, there are certain national institutions like the Gurukul Vishwavidyalaya, Vrindavan, whose degrees and diplomas are recognized by the Government of India as equivalent to the corresponding degrees and diplomas of a university for purposes of employment.

\section{Adoption Of Five Year Plan In Indian Constitution}

After freedom a government was formed at the central level with Pandit Jawaharlal Nehru as its Prime Minister, with commitment of socialist pattern of socialdevelopment in the line of U.S.S.R., whowas the only friendly country in the international arena at that period. Pakistan has already projected himself as our foe after 1947. Indo-Pak was caused due to partition of preindependence India on religious ground; USA was supporting Pak because of India's nearness with USSR. In the line of USSR where Joseph Stalin has already achieved growth by introducing five year plan system (FYP) in 1920 and most of the other countries either communist or non-communist have adopted FYP system of development.India also decided to go through FYP

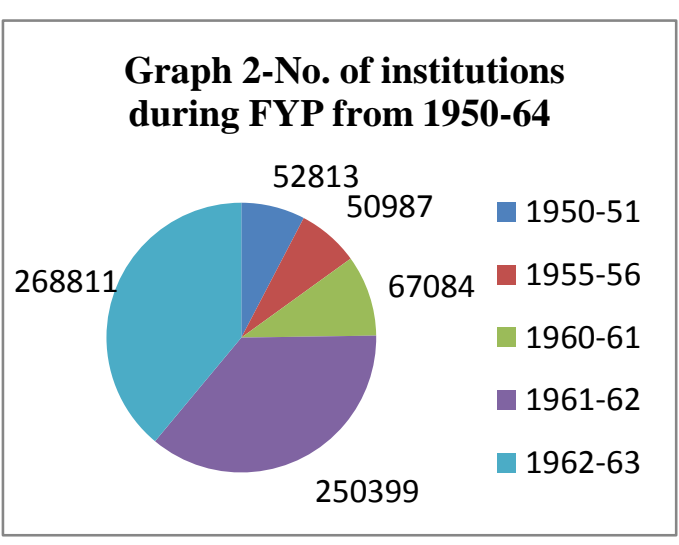
and in 1951-56 the then Prime Minister Pandit J.L. Nehru passed itfrom Indian parliament. In the constitution of Republic India education was placed in the state list and sole responsibilityof education went in the portfolio of state government.

\section{Plan Allocation}

The Indian constitution has provision to ensure that State provides education to all its citizens. The Indian constitution in its original enactment defined education as the state subject under Article 42, but realizing its importance for the development of the nation. Budgetary provisions were made through different agencies like UGC, NCERT, and CSIR etc. At the same time in the beginning of plan period (1950-51) a working partnership has been evolved between the Centre and the State Governments to implement development plans of education particularly higher education research and training of international standard. Most of the schemes are formulated and implemented by the State Government with assistance from Central Government. Whereas some centrally sponsored schemes were implemented by the State Governments. A Central planning and implementation group was in operation under the

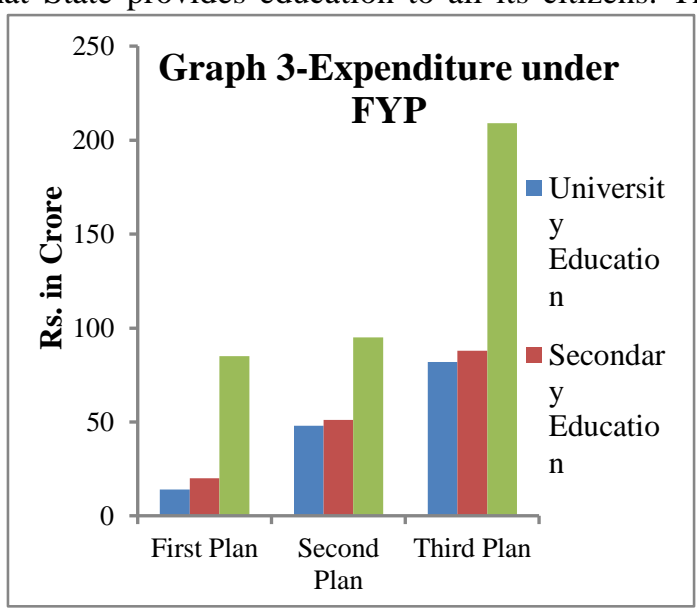


Chairmanship of Union Education Minister. The fund distribution outlay during our study period [1947-1964] together with their achievements isshown in graph.

\section{Cash Infusion In Higher Education 1947 - 64}

Under the Prime Minister ship of Late Pt. Jawaharlal Nehru a great farsighted statesman the educational explosion has taken place in India as reflected in its educational expenditure. At the time of independence only Rs. 55.0 crores spended in higher education which has increased many folds in the coming years noted in the table. A section of the Indian society argue that higher education in India is over invested during Nehru's Period, but it is not the reality most of the universities in India whether central and state, affiliating or residential, general or technical, vocational or professional, sports or cultural every fields are facing financial exigency. Sizable amount of material or non-material resources must be infused into education for education process to take-place and yield some quality output. During 1950-51 expenditure on education was 1.1 percent of the GND, and (1950-60) average was 1.8 percent. Birth of IITs, UGC, NCERT, and series of such institutions has created very strong foundations of prospering India. For a poor country like India at low level of economy has a very large competing claim for priority for higher education from other sectors the significance of this attainment can never undermined. Educationists have been demanding 10 percent of total plan outlay for educational process; however 8.7 percent of the total outlay fined in FFYP. But due to urgency of other sector plan outlay gradually went down in 2FYP, in 3FYP and in 4 FYP it went upto 5.1 percent and reached 4.6 percent in 5FYP.

However, after first decade of independence the fiscal exigency of the governments are reflected inits plan out way finding hard to preserve the quality gain. For the improvement of quality Govt. was serious to have alternative source of funding in higher Education. Per student expenditure has been compressed and higher educations and Universities of India went to reverse gear. Voices have been raised from various corners that higher education falls under non-merit goods category or purely private goods.

Table 4: Pre-independence state-wise break-up of expenditure 1944-47 (Rs. in Crores).

\begin{tabular}{|c|c|c|c|c|}
\hline Provinences & $\begin{array}{l}\text { Total Indirect } \\
\text { Expenditure }\end{array}$ & Universities & $\begin{array}{l}\text { Arts and Science } \\
\text { Colleges }\end{array}$ & $\begin{array}{l}\text { Technological, } \\
\text { Professional and Training } \\
\text { Colleges }\end{array}$ \\
\hline Assam & 2,774 & - & 1,347 & 17 \\
\hline Bengal & 13,623 & 4,946 & 8,079 & 2,357 \\
\hline Bihar & 5,876 & 870 & 2,067 & 925 \\
\hline Bombay & 11,683 & 2,492 & 5,711 & 3,132 \\
\hline C.P. \& Berar & 4,158 & 429 & 1,308 & 913 \\
\hline Madras & 23,832 & 3,922 & 6,971 & 4,116 \\
\hline N.W.F.P. & 824 & - & 640 & - \\
\hline Orissa & 2,204 & 254 & 973 & 374 \\
\hline Punjab & 10,744 & 3,415 & 6,202 & 2,867 \\
\hline Sind & 1,580 & - & 910 & 558 \\
\hline United Provinces & 19,713 & 6,578 & 8,407 & 2,114 \\
\hline Ajmer-Merwara & 219 & - & 129 & 57 \\
\hline Baluchistan & 318 & - & - & - \\
\hline Bangalore & 862 & - & 85 & - \\
\hline Coorg & 72 & - & - & - \\
\hline Delhi & 1,485 & 1,044 & 793 & 1,227 \\
\hline $\begin{array}{l}\text { Minor } \\
\text { Administrations }\end{array}$ & 382 & - & 292 & - \\
\hline Total & $1,00,349$ & 23,950 & 43,914 & 18,657 \\
\hline
\end{tabular}

\section{Technical Education}

Before independence the conditions andpopulation of Technical education was also measurable. Vocational and technical education was setup but they were poorly developed, both at the school and university stages, and the supply of high level trained scientific man-power was very limited. Educational inequalities were very large, especially between one region and another, between urban and rural areas, between men and women, and between the advanced and intermediate castes on the one hand and the scheduled castes and tribes on the other. The standards of education were generally unsatisfactory, especially at the school stage, with too much of emphasis on English and too little stress on mathematics, science or the Indian languages. The percentage of literacy was only about fourteen the pre-eminent sake behind this comparatively disgraceful literacy rate is the dearth of proper schooling system including the lack of infrastructure and the total educational expenditure was 
just about Rs. 570 million or less than half a per cent of the national income. It was challenging situation which the nation was called upon to reform when it kept its first tryst with destiny in 1947.

In the year 1946 post world war-II situation was reviewed and Sir Jogendra Singh executive council of viceroy set up a 22 members Committee headed by Nalini Ranjan Sarkar to create higher technical institution in India to fasten industrial growth in the line of western countries who have developed with the support of modern technologies.Sir N.R. Sarkar, in its report recommended the establishment of four Higher Technical Institutions in the eastern, western, northern and southern regions exactly in the line of USA with direction that these institutes will not only produce graduate / post graduate engineers but engaged in manufacturing technical teachers, researchers and providing technical knowhow to Indian industries also. On the recommendation of Sarkar Committee first Indian Institute of technology came into existence on the soil of free India in May 1950 in eastern India in Midanapur District of W.B. at Kharagpur. It started functioning from 5-esplanade, East Calcutta and shifted to Higili Detention Camp Building in September 1950 to pay respect to our freedom fighters who were mercilessly detained of being a solder of freedom struggle. On $18^{\text {th }}$ Aug 1951 by the then education minister Maulana Abul Kalam Azad the present name IIT was adopted with 42 teachers and 224 fresher.

In the year 1956 an act was passed from Indian parliament IIT (K)-Act and foundation stone of new building took place on 21.4.1956 by Prime Minister of India Late Pt. J.L. Nehru, the great visionary of future India.

At the closing period of FFYP it was decided by the Union government to set up five IITs in the chain of IIT-Kharagpurthat had started functioning in 1951. IIT-Bombay and IIT-Madras admitted the first batch of students in 1958 and 1959 respectively and IIT-Kanpur in 1960. The college of Engineering and Technology established in Delhi was elevated to the rank of IITs in 1963.All these IITs will provide international level technical education to +600 under graduate and 400 post graduates and research level students. Delhi institute will have strength of 1250(UG) and 300(PG). IIT Kharagpur will have target of 2000(UG) and 400(PG) students. IIT Kharagpur, Bombay and Madras have introduced special 3-years B.Sc. Course also. At undergraduate level teaching of Aeronautical Engineering has also been started in IIT Kharagpur and Kanpur to strengthen our civil aviation project. At Calcutta and Ahmedabad two management institutes has also been started on collaboration with UNO from its special fund. Industrial Engineering course was also started in Bombay to produce 1400 technocrat per year

\section{Figure -State wise Distribution of Engineering and Technical Institutions at the end of my study period}

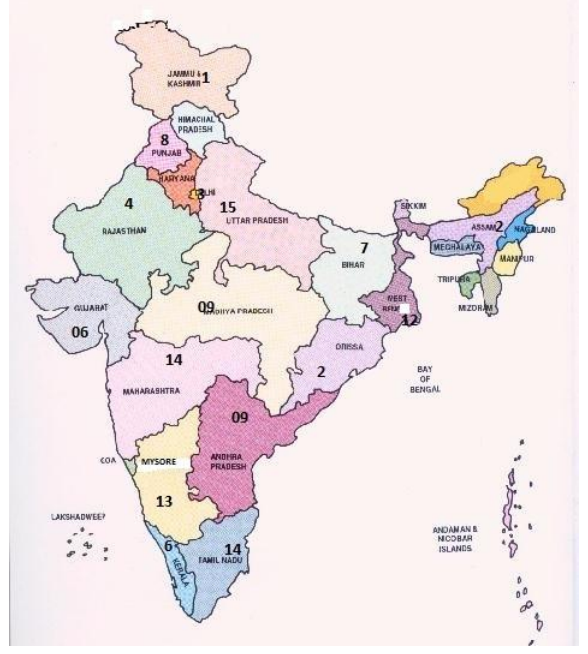

Tata Institute of fundamental research was established at the initiative of noted nuclear scientist Homi Jahangeer Bhabha in 1944 with financial help from J.R.D. Tata Chairman of the Tata Group. TIFR came into existence on $1^{\text {st }}$ June, 1945 with H.J. Bhabha as its first director and started functioning from Indian Institute of science, Bangalore and shifted to Bombay in the same year. Its new campus at Colaba-Bombay was designed by Chicago Architect Helmuth Bartsen and inaugurated by the then PM of India Pt. J.L. Nehru on 15 ${ }^{\text {th }}$ Jan, 1962. TIFR was entrusted to be the largest nuclear research centre now it has acquired the status of deemed University it was the far sightedness of Pt. Nehru. At present its main organs are (a) School of Mathematics (b) School of Natural Sciences (c) School of Technology and Computer Science (d) Department of Biological Sciences and others. It is now a world class centre of theoretical studies of latest Science and Technology with emphasis of Atomic Physics and computer Science. 


\section{Village Oriented Higher Education}

On the recommendation of the rural Higher Education Committee a National Council for Higher Education in Rural Areas was established in 1956 to advise the Government on all matters relating to the development of rural higher education. The council has selected 14 institutions for development into rural institutions and these have started functioning at Sri Niketan (W. Bengal), Gandhigram (Madras), Jamianagar (Delhi), Udaipur (Rajasthan), Birouli (Bihar), Bichpuri (U.P.), Sanosara (Gujarat), Coimbatore (Madras), Gargoti (Maharashtra), Amravati (Maharashtra), Rajpura (Punjab), Wardha (Maharashtra), Hanumanamathi (Mysore), Thavanoor (Kerala), and Indore (Madhya Pradesh). Recognition of the diploma in rural sciences as equivalent to a first degree of a university for purposes of employment has been secured. It is also recognized by the Inter-University Board and certain universities for post-graduate studies in specified subjects. The diploma course in civil and rural engineering has been recognized by the All-India Council of Technical Education and some state governments for appointment to subordinate services and posts. The two year certificate course in agricultural science and the sanitary inspectors' course have been recognized by most of the State Governments. A concurrent course of general education and teachers training of three years' duration after the higher secondary stage has been introduced as a pilot project at the Rural Institute at Gargoti.

\section{Community Education}

Social education provides an educational base for community development programmes in the country and includes literacy, use of libraries, education in citizenship, cultural and recreational activities, and utilization of audio-visual aids and organization of youth and women's groups for community development. A National Centre for Fundamental Education has been established in New Delhi to train higher grade personnel for social education work, develop suitable techniques, carry out research on selected problems and serve as a clearing house of information. The library institute set up at the Delhi University performs similar functions in the field of libraries. The Government of India also run the Delhi Public Library as a pilot public library project. A social education Institute for workers has also been set up at Indore; Janata colleges and vidyapeeth are providing continuous educational facilities for adults in rural areas. After independence the Imperial library of 1836 was re-named as National library of India through enactment of Imperial Library (change of name) Act-1948. On 1st February 1953, the National library was opened to the public, inaugurated by Maulana Abul Kalam Azad with B.S Ksram as its first librarian. The then Prime Minister of India Late Jawaharlal Nehru laid the foundation stone of the existing building in May 1961.

\section{Education Of The Physically Disabled Person}

A National Advisory Council advises the Government on all problems concerning education, training and employment of the physically and mentally handicapped. The National Centre for the Blind at Dehra Dun provides an integrated service for the blind. A national library at the Centre caters to the needs of the blind throughout the country. A training Centre for the adult deaf has been established at Hyderabad. Special employment exchanges for the handicapped located Ahmedabad, Bangalore, Bombay, Calcutta, Chandigarh, Delhi, Hyderabad, Kanpur and Madras help to place the handicapped in suitable occupations.

\section{Youth Welfare, Physical Education, Sports And Culture}

So far extracurricular activities was concerned a committee was set up under the chairmanship of Kunjuru who in Dec 1963 mad some recommendation regarding physical education ,youth activities ,culture etc. the motive of the recommendation was to activate and introduce (i)Organisation of annual inter-university youth festivals and assistance to universities for the organisation of inter-collegiate festivals; (ii) travel concessions and financial assistance for organising youth tours to places of historical, scenic and cultural interest and to development project areas; (iii) assistance to the Youth Hostels Association of India and State Governments for setting up youth hostels all over the Country.

The $9^{\text {th }}$ Inter-university Youth Festival was held in New Delhi between $14^{\text {th }}$ and $21^{\text {st }}$ November 1964 . The Lakshmibai College of Physical Education, set up at Gwalior in 1957, to provide training facilities for a three year degree course and also for post-graduate studies and research, is progressively expanding its activities. To create consciousness in the general masses of the need of being physically fit, a scheme of National Physical Efficiency Drive was launched in 1960. In view of the national importance of the Drive the Government of India has also instituted National Awards for those revealing proficiency of a very high order in physical ability.

Encouragement offered to the organisation of sports has been in the following directions:-All-India Council of Sports, for the purchase of sports equipment, sending Indian teams abroad, inviting foreign teams to play in India, holding national championships, etc.

A National Institute of Sports established at Patiala in 1961 has so far trained 548 coaches. The AllIndia Council of Sports advises the Government of India and the Sports Federations in the matter of development of games and sports in the country. 


\section{Conclusion}

Besides rapid extension to attain high growth rate, trained technocrats, trained financial and business manager for international needs, the maintenance of standards in higher education is extremely crucial because an education without quality can do infliction than boon. In Indian testaments the source of strength was trusted with education ref. Chanakya Neeti 2.16.

\section{budhiryasya balam tasya, nirbhdhe Stu Kuto balam|} wane singho madanmantah shashken nipatitah\|Chanakya Neeti.2.16

Meaning hereby knowledge is the powerhouse of strength and force. Through this article I am discussing the prevailing scenario of higher education about the past for which I was not the witness but situation is being transmitted to me by our ancestors that during pre-independence period one has to move miles and miles to search a person whowill read his letters that he has received from someone, one have to go milesmiles for schooling and what to say about Universities and Colleges.

Bringing higher education to the approach of general public in the post-independence period solely credited to Pandit Jawaharlal Nehru. He use to address through his speeches that IITs, Universities Bhakhra Nangal Dam, Koshi irrigation project etc. are the temple, mosque, churches and Gurudwara's of independent and prosperous India whereas he himself was brought up in international culture and social environment so he was realizing and seen from very nearness how west have developed so rapidly using modern technologies. All these reflect in his first convocation address of IIT-Kharagpur in 1956 from its camp building Higili Detention Camp recited as.

"Here in the place of that Higili Detention Camp stands the fine monuments India, representing India's urges, India's future in the making. This picture seem to me symbolical of the changes that are coming to India"

- Late.Pandit J.L. Nehru at IIT 1956

Again on October 1963 at the ceremony to mark the dedication of the Bhakra-Nangal Project to the Nation, Prime Minister Late.Pandit Jawaharlal Nehru said,

"This dam has been built with the unrelenting toil of man for the benefit of mankind and therefore is worthy of worship. May you call it a Temple or a Gurudwara or a Mosque, it inspires our admiration and reverence".

$$
\text { - Late .Pandit J.L. Nehru in } 1956
$$

I am really very much astonished when in course of my Ph.D. work in Physics I was in IIT Kharagpur Kelkar Library and looking there the thrust of younger generation towards earning knowledge once again I don't stop myself in telling how farsighted was Pandit Nehru? How dedicated he was for higher education? How worried he was for India's future? How committed he was for betterment of Bharat Mata? If we see on one side present Global importance of IITians and vision of Pt. Nehru that he was looking half century ahead really I salute once again for making India a strong prosperous country and we are enjoying the gift of that great-great statesman Late Mrs Indira Gandhi has also recognized the importance of education in human life.

"Education is a liberating force, and in our age it is also a democratizing force, cutting across the barriers of caste and class, smoothing out inequalities imposed by birth and other circumstances."

- Late. Smt. Indira Gandhi

When Nehru passed away the population of India has enhanced to by $22 \%$ as compared to the time of liberty, whereas demographical area has gone down as China has acquired some part in 1962 aggression. The population density has increases from 110 person / kilometre ${ }^{2}$ to 134 person/kilometre ${ }^{2}$

During each FYP the condition of universities becomes better in all dimensions of it.The total number of recognised institutions, enrolment there in, the number of teachers and expenditure incurred on them is shown below

Table 5: Post-independence growth of Institutions with expenditures

\begin{tabular}{|c|c|c|c|c|c|c|}
\hline Year & $\begin{array}{c}\text { Number of } \\
\text { institutions }\end{array}$ & $\begin{array}{c}\text { Number } \\
\text { Of students } \\
\text { on rolls } \\
\text { (in lakhs) }\end{array}$ & $\begin{array}{c}\text { Number of } \\
\text { teachers(in } \\
\text { lakhs) }\end{array}$ & $\begin{array}{c}\text { Direct } \\
\text { expenditure (in } \\
\text { crores of } \\
\text { rupees) }\end{array}$ & $\begin{array}{c}\text { Indirect } \\
\text { expenditure (in } \\
\text { crores of } \\
\text { rupees) }\end{array}$ & $\begin{array}{c}\text { Total } \\
\text { expenditure (in } \\
\text { crores of } \\
\text { rupees) }\end{array}$ \\
\hline $1950-51 .$. & $2,86,860$ & $2,55.43$ & 8.04 & 91.05 & 23.33 & 114.38 \\
\hline $1955-56 .$. & $3,66,641$ & $3,39.24$ & 11.07 & 144.81 & 44.85 \\
\hline $1960-61$ & $4,72,655$ & $4,79.63$ & 15.08 & 257.17 & 86.94 \\
\hline $\begin{array}{l}1961- \\
62 \text { (Revised) }\end{array}$ & $6,86,359$ & $5,43.55$ & 16.53 & 292.68 & 103.21 \\
\hline $1962-63^{* *}$ & $7,22,280$, & $5,67.15$ & 17.24 & 317.63 & 344.11 \\
\hline
\end{tabular}


Table6: Post-independence growth of Institutions during 1950-66.

\begin{tabular}{|c|c|c|c|}
\hline Year & No. of Universities & No. of Affiliated Colleges & Total Enrolment \\
\hline $1950-51$ & 27 & 695 & 362223 \\
\hline $1955-56$ & 33 & 1025 & 608255 \\
\hline $1960-61$ & 45 & 1542 & 895541 \\
\hline $1965-66$ & 64 & 2572 & 1463719 \\
\hline
\end{tabular}

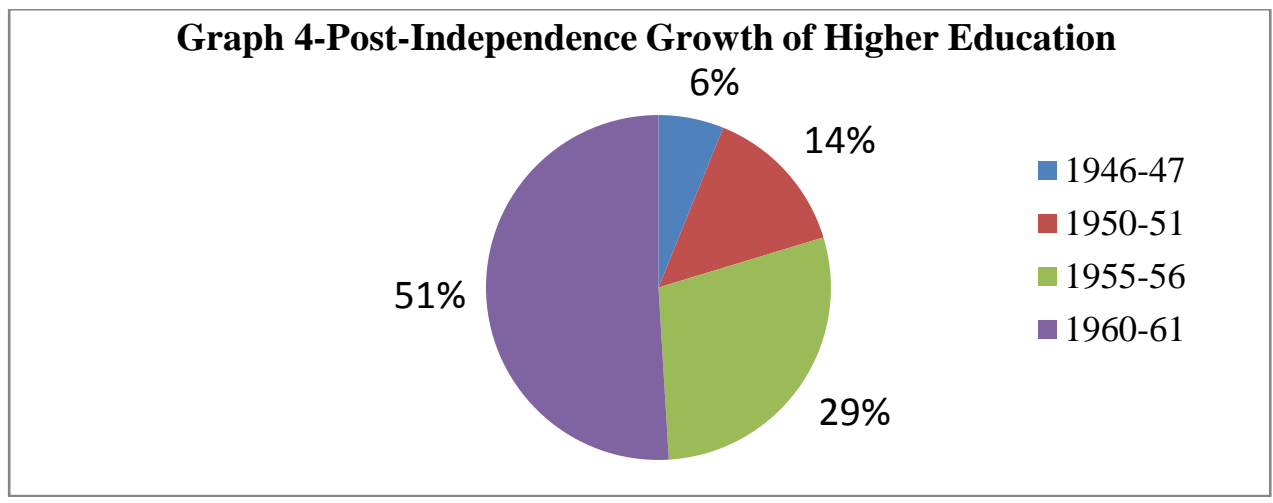

A working partnership has been evolved between the Centre and the State Governments to implement development plans of education. Most of the schemes are formulated and implemented by the State Government with some assistance from the Centre. Of the centrally sponsored schemes, some are implemented through the state Governments and others are directly by the Central Government. A central planning group, with the Union Minister for Education as its Chairman, is already working on a long term development plan covering the period 1966 - 81. The distribution of out-lay in the First, Second and Third Plans is set out below.

\section{Recommendation}

At this stage of my finding is the first that I am reportingmy final recommendation will be communicated at the closing point of the study of this project. However, I recommend that quality of the opening work is highly appreciated and full of nationality and with the target to make an incredible India. As my project is to review the educational system of India right from Independence Day in different segment hence at this stage any recommendation is not apropos. However it is observed that in any society the human resources structure can be represented by a pyramid but unfortunately in India the structure of our human resources are in the form of hourglass. There is huge number at mid and top level professionals, exdoctors, engineers, lawyers of an indifferent quality. India has more electrical engineers than electrician more civil engineers than Mason, more super specialist doctors than general physicians, more

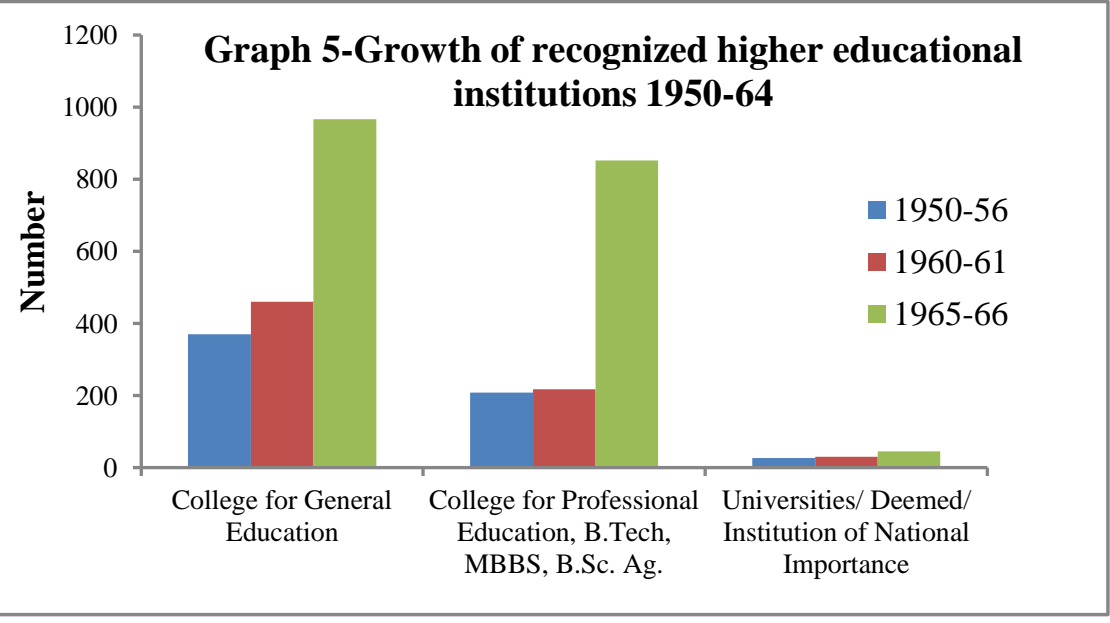
mechanical engineers than mechanics..

\section{Research Findings}

On peer review of the expansion in the field of higher education the far sightedness of Late Pt. Nehru it may be written in golden letters, his high thinking, relentless commitment for the motherland has made a impregnable endowment of higher \& technical education in the country. What we are facing in 2014, Pt. Nehru has visualized the same as early as 70 years ago in 1950 by establishing IIT's, UGC,NCERT, etc. the global demands of IITans, their achievements in information technology and in the field of biotechnology, field of management field of information. I observed and recommend that all decisions taken in the field of higher 
education were recommendable, sustainable and more and more suitable for the present situation and in the coming times also.

One of the finest finding of the study during the period 1947-64 is the birth of IITs, however UGC, NCERT and many other such institutions. Jawaharlal Nehru the architect of modern India and creator of the IITs focussed on the long term economic and spiritual wellbeing of all Indians. Indian parliament has declared IITs as the institutes of "National Importance". Nehru started building elite institutions in 1950. China made a similar move in the 1990s. The period 1947-64 is the resurgence of India as a nation competitively endowed in science technology and higher technical education can be traced to be the vibrant current of 1947 when to India's great fortune, Jawaharlal Nehru took charge as country's first prime minister, this visionary venture to setup a group of institutions starting from IIT Kharagpur in 1950 and onward. There consistence performance assiduously kept up in the last 50 years has attracted not only nation wise acclaim for them but provided them international commendation. At one time the ICS and later on IES examination conducted throughout the country enjoyed a great reputation. Here, "it may not be an exaggeration to state that JEE held in the recent times has perhaps eclipsed these and myriad another competitive examinations.

President Sarvapalli Radhakrishnan, while addressing the first convocation of the second IIT, IIT Bombay at Mumbai on December 22, 1962, warned both India and the IITs against drifting from their original promise.

"The strength of the country is judged not by the number of millionaires."

It has created, but by the poverty it eliminated and yet, both India and the IITs have drifted away from their original goals. More than 80 percent of the cost of IIT education for the students, who came largely from the top 10 percent income group in India? The IITs were supposed to lead the nation in R\&D and they were supposed to educate Ph.D. students who would lead R\&D in India's industries and serve on the faculties of India's other technical institutions. The IITs would thus have created a multiplier effect and a culture of innovation throughout the country.

The international competitiveness of the IIT undergraduates is reflected in their performance at the Graduate Record Examination (GRE) of the USA, an examination for graduates from all over the world; a comparison of the performance levels at the GRE between IIT, B.Techs and those of the three of the best institutions in the word as represented below:

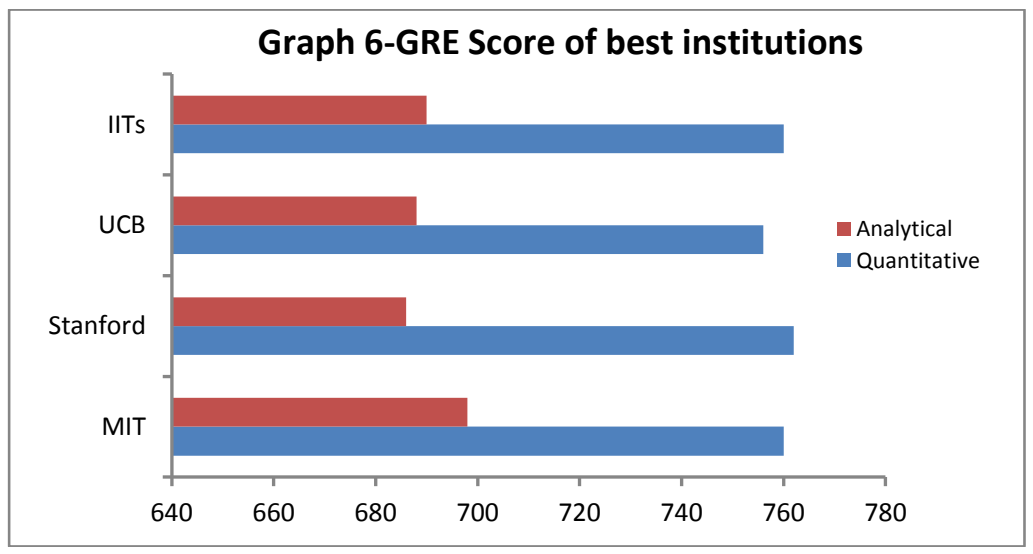

The 58 years after the birth of it's the achievement of institution may be judged where an American TV used magazine in its 60 minutes of telecast described these institutions Harvard, MIT and Princedom put together. The World Bank Task Force has also declared "The best higher education is a model and a source of pressure for creating a modern civil society. This is an ideal not for often realised but is nevertheless a standard against which to measure national systems"

Accepting the potentiality of this IIT US ambassador Powell said that we are actively encouraging more American students to study and explore India through new initiatives called "PASSPORT TO INDIA".

Powell earned IITians to create apps (mobile applications) in a bid to transform India." Create apps that support nutrition health and child survival and literacy of girls. Private American companies in India are already engaged in research activities in places like Hyderabad and Bengaluru. We can do this (research) in English rather than having to learn Chinese.

\section{Acknowledgement}

I do acknowledge with gratitude to Publication Division Ministry of I \& P, Govt. of India and Dr. J Choudhary University Professor \& former Dean Students' welfare T.M.Bhagalpur University for encouragement in making this paper. I also acknowledge my husband Tathagat Priyadarshi for Information 
Technology and Computing support and my only three years old son in maintaining himself for peace as well as my mother-in-law for her continuous support and blessing during the whole research work.

\section{Reference}

[1]. “Ambassador Powell Highlights Importance of IITs at PanIIT Global Conference”, by INDIA AMERICA TODAY News Service, cited on 22/4/2014.

[2]. Adhyatma Ramayan

[3]. Aggrawal J.C. and Aggrawal S.P. Education Planning in India: Reports of Committees and Commissions five year plans, statistical tables, concept publishing, new Delhi, 1992, pg. 220

[4]. Banerjee, Rangan and Muley Vinayak P. "Engineering Education in India” IIT Bombay, Powai, Dec 16, 2008.

[5]. Basu, B.D; "History of Education in India under the Rule of East India Company", Gauranga Press, 1867.

[6]. Bhagawad Gita

[7]. Chanakya Neeti

[8]. Development of Higher education during different plan periods since 1951" - Directorate of Higher Education, Govt. of Assam.

[9]. en.wikipedia.org - Jawaharlal Nehru cited 20.04.14

[10]. Govt. of India, Department of Economics Affairs [DEA] Government subsidies in India", New Delhi, Ministry of Finance, 1997.

[11]. India Education Report (2005) - NCEE.

[12]. Mahabharata puran

[13]. Mishra, Surya Narayan, "Higher Education and Nation Building in India", KIIT Univ. Bhubneshwar, Sept. 2011.

[14]. Naik J.P, "Policy and performance in Indian Education" 1947-74" Indian Council of Social Science Research, New Delhi

[15]. Neeti shatak

[16]. Panchamukhi, P.R; “Compressing Higher Education Budgets: Some Reflections.” University News 1998.

[17]. Ramachandran, C.M. "Problems of Higher Education in India: A case study, Mittal Publication, Delhi, 1987.

[18]. Review of Pre-independence period - NCTE report.

[19]. Sathpath brahman

[20]. Shri shri Vishnu Puran

[21]. Shrimad Bhagwat

[22]. Singhal ,Kalyan; “A Renaissance of Indian Institutes of Technology”, THE HINDU, cited on 22/4/2014

[23]. Tilak, JBG “The Dilemma for Reforms in Financing Higher Education” Policy, International Association of Universities, Elsevier Science Ltd, No. 10.1, 1997. 